\title{
The capital of pulp fiction and other capitals \\ Cultural life in Medan, 1950-1958
}

Marije Plomp

The general picture of cultural activities in Indonesia during the 1950 s emanating from available studies is based on data pertaining to the nation's political and cultural centre, ${ }^{1} \mathrm{Jakarta}$, and two or three other main cities in Java (Foulcher 1986; Rhoma Dwi Aria Yuliantri and Muhidin M. Dahlan 2008). Other regions are often mentioned only in the framework of the highly politicized debate on the outlook of an Indonesian national culture that had its origins in the 1930s (Foulcher 1986:32-3). Before the war, the discussions on culture in relation to a nation were anti-colonial and nationalistic in nature, but after Independence the focus shifted. Now the questions were whether or not the regional cultures could contribute to a modern Indonesian national culture, and how they were to be valued vis-à-vis that national culture. What cultural life in one of the cities in the outer regions actually looked like, and what kind of cultural networks - national, transnational and transborder - existed in the various regions has yet to be researched.

With this essay I aim to contribute to a more differentiated view on the cultural activities in Indonesia in the 1950s by charting a part of the cultural world of Medan and two of its (trans)national and transborder cultural exchange networks in the period 19501958. This time span covers the first eight years of Indonesia as an independent nation until the start of the insurrection against the central army and government leaders by North Sumatran army commander Colonel Maludin Simbolon on 22 December 1958 (Conboy 2003:37-51). After 1958, this and other rebellious move-

1 I thank Peter Keppy (Netherlands Institute for War Documention, Amsterdam) for his references to literature and his useful comments on a first version of this paper and Alie Soekardi (Analisa newspaper, Medan) for the text of Zainuddin Pangaduan Lubis' speech 'Roman "picisan" dan kita'. 
ments in West Sumatra and Sulawesi led to changed relationships between the nation's political and cultural centre and the areas outside Java. Also, the Malayan Independence of 31 August 1957 and the subsequent return of many Malay nationalist writers from Singapore to Kuala Lumpur altered relations between Indonesian and Malayan cultural workers.

A study of the cultural life of Medan yields a different view on the common perception of Indonesian culture in the 1950s. Available studies on this period focus on the national, highbrow culture, but in Medan - and likely in other large Indonesian cities as well the cultural scene was dominated by popular culture, produced for and consumed by the masses. As it turns out, only a small section of city's inhabitants took part in the emerging 'modern' national culture. Although the first decade after Independence has been discussed in studies on forms of popular cultural expression, such as Frederick's article (1982) on the genesis of dangdut, popular culture with its exchange networks has not yet been compared to highbrow culture inhabiting the same geographical space. Research into the Medan world of Malay movies, pulp fiction, cartoons and popular music uncovers cultural networks different to those connected with self-consciously national culture. Moreover, it lays bare different directions of cultural exchange and highlights a changed constellation of centre and periphery.

Popular cultural forms and (trans)national exchange networks in Indonesia have not received the scholarly attention they deserve. Western-centric notions of artistic value and the subsequent dichotomy between high and low forms of cultural expression excluded the popular domain as an area for investigation. As most researchers focussed on the creation of a national identity through politics of culture, they turned to the discourse of the cultural elite in Jakarta. But as scholars such as Harper (1999) and Kahn (2006) have convincingly demonstrated in the case of Malayan cities, popular culture formed the breeding grounds of counter narratives of identity, and as such constitutes a fertile ground for further research. In Malaya, the British quest for an Anglicized vision of the 'Malayan' 'was defeated by an upsurge of explorations in ethnic and religious identity that emanated from networks within the vibrant popular cultures in the towns' (Harper 1999:275). Moreover, as popular culture caters to the taste of the public, research can yield new insights into how notions of nation, religion and ethnicity were experienced by the masses.

Medan in the fifties forms a unique area to investigate the interaction between a cultural periphery and the national cul- 
tural centre, Jakarta. Close historic ties between the east coast of Sumatra and the Malay Peninsula on the other side of the Malacca Straits made the region subject to forces different to those elsewhere in the archipelago. Before the war, contacts between the inhabitants of Medan and Jakarta had mainly served colonial purposes. Shared Malay language and traditions, strong kinship ties with Malays living on the other side of the Malacca Straits, and the close proximity to the Malay Peninsula, meant that a large number of the inhabitants of Medan and the east coast were economically, socially and culturally oriented towards Singapore and Malaya, instead of far away Java. Malays on either side of the Straits were like bambu serumpun, different shoots of the same bamboo. It was only after the rather sudden proclamation of independence by Soekarno and Hatta in Jakarta on 17 August 1945 that the Sumatrans saw themselves confronted with a new community of which they were part, the Indonesian nation-state, and they had to redefine themselves vis-à-vis this new nation and its leaders.

In my discussion below, following a short introduction of the city of Medan and its inhabitants, I address Medan's thriving popular culture and the related cultural exchange network between Medan and Singapore that formed part of the fluid continuum of what is called the Malay World. I then contrast this network with the relations of Medan-based authors of the 'high' modern Indonesian literature with their colleagues in the nation's cultural centre, Jakarta. Finally, I will return to the Malay connection in an analysis of the relations of the Malay writers-nationalists in Singapore with their fellow writers in Jakarta and other cities on Java. In the conclusion I create a map of the area in which Jakarta, Medan and Singapore, as main cultural centres, form a triangle, showing the different itineraries of cultural traffic between them.

\section{GITY AND CITIZENS}

The city of Medan has always been a cosmopolitan centre of commerce. Its geographic location - near the shore of the Malacca Straits on the one side, the foothills of the central mountainous area rich in minerals and timber on the other, and enclosed by fertile lowlands - made it a crossroads of traders of diverse ethnic descent. Malays, Acehnese, Toba Batak, Karo, Mandailing, Simalungun, Dairi Pak Pak, Acehnese, Chinese, Arabs, and Europeans passed through or took up permanent residence in what 
soon became the largest city of the island. From the last quarter of the nineteenth century until the outbreak of the Second World War, large numbers of Javanese were contracted as coolies for the plantations that sprang up in the lowlands (Stoler 1995: 1-7, 25-8).

For generations, the fertile and sparsely inhabited lowlands attracted Batak farmers from the mountainous interior, where the conditions for agriculture were difficult. Malay local rulers granted them land in exchange for their promise to convert to Islam. As members of a multi-ethnic Muslim brotherhood, and removed from their native community, a large number of them gave up Batak traditions, adopted a Malay/Muslim name and became 'Malay'. After the war, many of these 'Malays' moved to Medan for reasons of education, work or safety (to escape the danger caused by the war for Independence, the bloody social revolution of 1946, and the national army chasing the illegal squatters on plantation grounds in the fifties (Pelzer 1982). A similar process took place with Acehnese immigrants and descendants of Javanese coolies, and the result was a large, heterogeneous Medan Malay community.

Before the war, the city's inhabitants had numbered 80,000, but by 1954 the number had grown sixfold to half a million. In 1954, nine years after the end of World War II, Medan still suffered the effects of the Japanese occupation. Homeless former romusha (forced labourers during the occupation) and heiho (Indonesians who served in the Japanese army during the occupation) roamed the streets, together with those veteran freedom fighters whose return to society had failed. A whole generation of young adults were (partly) illiterate, because they had lacked proper education during the war. The rapid urbanization that had taken place after the war led to a myriad of problems. A shortage of land and houses resulted in large scale squatting and a stagnating economy. The city's public facilities were by no means sufficient for the increasing number of new inhabitants: schools, libraries, roads, transportation, markets and hospitals were in dire need of improvement or expansion. The influx of poor, illiterate farmers from the surrounding villages, combined with the effects of the Japanese occupation, was responsible for a high rate of illiteracy.

The officials of the municipal government and local branches of national institutions were determined to improve the situation. There was a Biro Rekonstruksi Nasional - a governmental organization founded to support veteran freedom fighters - that organized free vocational courses, granted loans to start up small 
businesses, and ran several companies, such as a car service station, offering employment to veterans. The municipal Department of Information set up literacy courses and small libraries, and installed radios in public places. In February 1954, the department distributed no fewer than 20,000 training books among the city's inhabitants in an effort to fight illiteracy, but without any significant result. For the poor, displaced and homeless, there were social counsellors, a shelter at the city's outskirts, and in some cases even a free ticket home. Free courses to increase the population's general knowledge were open to all citizens. And with the first ever democratic national elections coming up in 1955, the Department of Information organized public lectures, movie screenings and gatherings for students to instil patriotic support of modern democracy in the hearts and minds of the people of Medan.

The large number of political organizations, and women's, workers' and students' associations in Medan attest to the grass root level support for the activities directed at social and economic development undertaken by the local government. The citizens' concerns over and engagement with the city's and the nation's welfare also came to expression in the 14 local newspapers and about the same number of news and entertainment magazines published locally (Buku tahunan 1955).

Thus a lot was done, but it was not enough. The recent economic recession had strained the city's budget. In Medan, it was felt that it was time the central government in Jakarta stepped in and increased its contribution to the city's budget, which at that time stood at one third of the total budget. When the central government refused to do so, local dissatisfaction with the nation's leaders in the capital grew. Local media voiced sharp criticism of the country's leadership. The central issue was the unequal division of the nation's incoming funds by the central government. Time and again, it was argued that while Sumatra's natural resources - especially mining and the extraction of oil had filled the nation's treasury, the island had not participated in the accumulated wealth. President Soekarno and Premier Ali Sastroamidjojo cum suis were openly criticized, not only because of the seemingly unfair division of funds, but also because the people of Medan - like elsewhere in Indonesia - realized that Soekarno's promises for socio-economic improvement had failed to materialize. The results of the 1955 elections showed how deep the divide had grown: Sumatra had become a MASJUMI party (Majelis Sjura Muslimin Indonesia, Consultative Council of Indonesian Muslims) stronghold against the aspirations of the ambi- 
tious political party of Soekarno, the Partai Nasional Indonesia (PNI, Indonesian National Party), whose supporters dominated the political scene in Java (Feith 1999).

POPULAR CULTURE AND THE MALAY WORLD

Unlike what one would perhaps expect from areas at a great distance from the nation's cultural centre, cities on other islands - both the main urban regions and mid-sized cities - possessed a lively cultural scene in the period under discussion. As Barbara Hatley shows in her contribution to this volume, several cities in Sulawesi were host to a variety of cultural activities. In Bali, LKN affiliated writers and performing artists were very productive, as Nyoman Darma Putra demonstrates in his study also in this volume. Melani Budianta's essay describes the diverse cultural circles of her hometown Malang where she lived as a child.

Despite the dim economic prospects - or perhaps because of it,$-^{2}$ Medan had a vibrant cultural life. As for production and consumption, it was popular culture that had the upper hand, as opposed to expressions of more serious, self-consciously modern Indonesian culture. Visual forms of popular culture such as films and cartoons - both relatively new media - appealed to wide public consumption, not least because of the city's high rate of illiteracy. In this respect, Medan resembled the main cities on the Malayan peninsula where, much to the chagrin of the British educators, 'plebeian tastes' ruled and the public preferred a sentimental Malay or Hollywood movie over a good novel (Harper 1999:282). It is telling that in Medan, bea tontonan - local taxes on cinema tickets - accounted for no less than one third of the total municipal budget. There were at least 16 movie theatres that screened Hollywood, Indian and Malay movies featuring prominent singers (Buku tahunan 1955:24, 219). Records of film music and songs from Malay movies from Singapore and the Federation of Malaya (Malaya as of 31 August 1957) such as Hang Tuah with musical arrangements by the popular Malayan actor, singer and songwriter P. Ramlee, found their way to fans in Medan.

Radio was another popular medium. The Medan studio of Radio Republik Indonesia (RRI) was frequented by popular singers, choirs, and bands. Lily's Band, led by singer/composer Lily

2 Compare the popularity of cabaret, theatre and other forms of amusement such as soccer games in the Netherlands during World War II. 
Suhairy, was the largest and most renowned musical ensemble of Medan. Famous singer of Malay songs Rubiah was also a member of Lily's Band; her voice was used to dub popular Malay movies from Singapore at the time. Another popular singer/songwriter from Medan whose Malay songs were aired by RRI was Achmad CB. Partly raised in Malaya, this international 'king of keroncong' - he had won the acclaimed Singapore keroncong contest three years in row - recorded his songs in Singapore. Other genres that gained popularity in the fifties were modern Batak song, gambus and nasyid, the latter two inspired by music from the Middle East. Lastly, bands, choirs and musical ensembles from Java and other islands regularly performed in the studio of RRI Medan, as well as in other venues in the city. Besides music, RRI had literature programs and poetry readings that enjoyed a high popularity.

In the mid-1950s, Medan was known as the capital of pulp fiction'. Private printing and publishing in Indonesia had begun in Medan in the first quarter of the twentieth century, and from the start, the Medan printing houses had catered for the market. About half of all publications found throughout Indonesia in the 1950s were printed in Medan (Barus Siregar 1953). But it was not so much the quantity as much as the quality of these publications that set tongues wagging at the time. While there was hardly a market for 'serious' modern Indonesian literature in Medan, popular fiction featuring robbery, murder, smuggling, love and sex sold exceptionally well, especially amongst the youth. ${ }^{3}$ Not surprisingly, critical remarks on this popular genre can be found in abundance in the national cultural pages and magazines published in Java dedicated to modern Indonesian literature and national culture, such as Kompas, Zenith and Merdeka. Film director Usmar Ismail, for instance, felt that these stories had nothing to offer to the readers, except shallow emotions, cheap sentiments, and moral irresponsibility, and that they would ultimately poison the mind (Barus Siregar 1953:24). The content of these roman picisan together with the images of female singers and movie stars in the entertainment magazines deemed 'obscene' by many, earned the city its questionable epithet (Nasution 1955:261).

The negative appraisal of writings from Medan after the war was partly based on pre-war colonial Dutch ideas about literature that continued to exert their influence after the Dutch had lost their dominant position in Indonesia. With the founding of the government printing house Balai Poestaka (BP) in 1908, the Dutch set a standard of what constituted good literature (Teeuw

3 In this genre, Joesoef Sou'yb and Narmin Suti were two of the most prolific writers in Medan. 


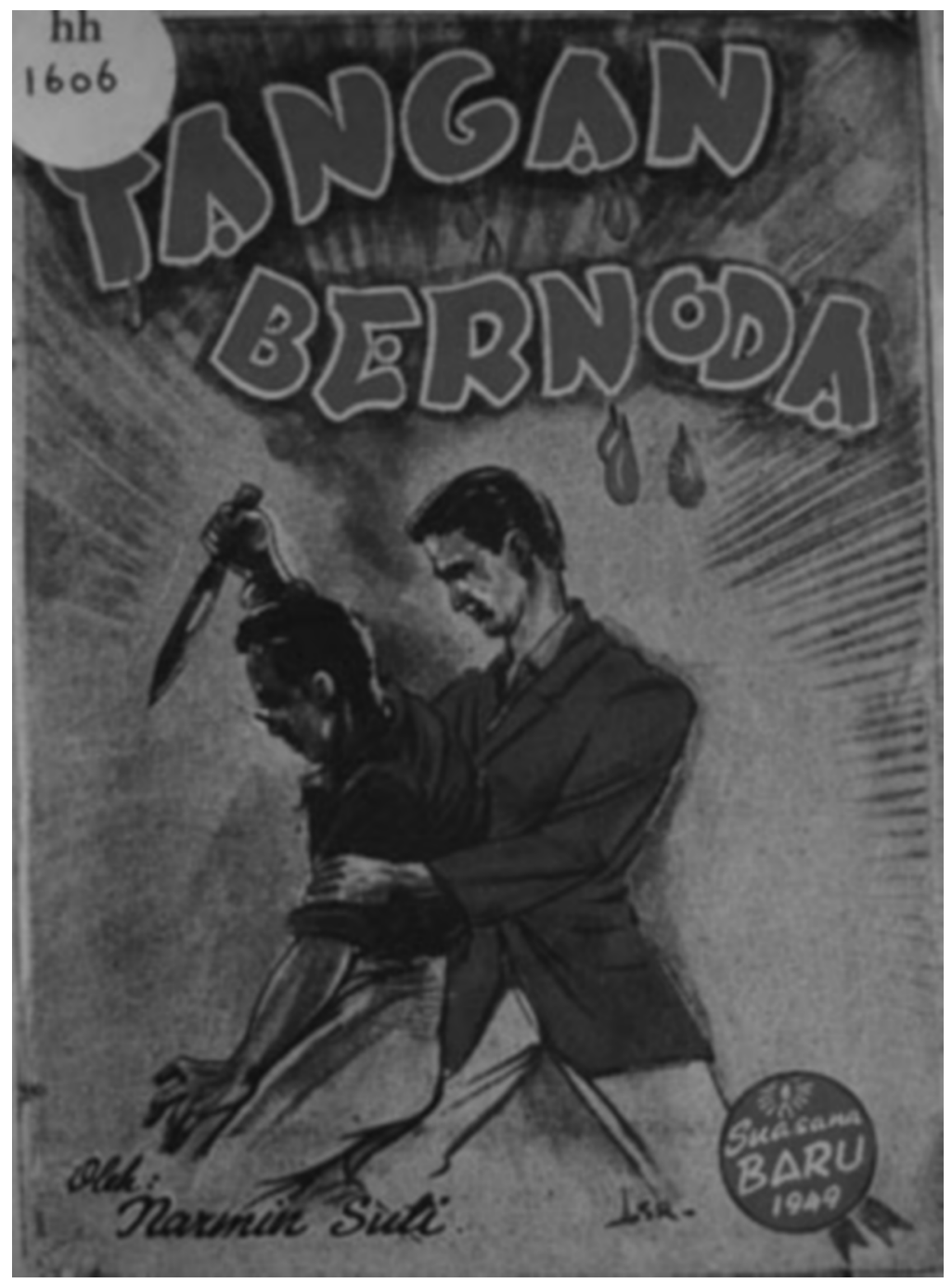

'Tangan bernoda'. (Narmin Suti) 
1986:13-5). Fiction that did not meet the Dutch literary standard was called sastra liar: literature that was 'wild', 'untamed', written by authors who did not abide to 'the rules of literature'. But this standard was set up with colonial interests in mind, more than literary merit. Literary texts addressing religion, race, and politics were deemed to be dangerous to the colonial enterprise, and thus labelled sastra liar. Moreover, if the Malay language used in a literary text did not meet the Dutch standard of what was proper Malay or Indonesian, it was rejected as well. As several Sumatran writers and playwrights from before the war voiced their anticolonial critique in their works, many of their texts were seen as sastra liar. Yet one must bear in mind that this artificial boundary was not as fixed as it seems. Kratz (1991:194-5) for instance, has shown that a survey of literary magazines and light entertainment magazines reveals that even the recognized authors frequently published in magazines rarely mentioned by critics. Following the same line of thought, Teeuw (1986:73-5) mentions Hamka's stories that were first published as roman picisan and later taken over by Balai Poestaka.

Another pejorative label pertaining specifically to texts from Medan was sastra Medan. It referred to the works of Hamka and his fellow Muslim authors from Medan, which were more nationalistic and political then those written in Batavia (Roolvink 1950 cited in Kratz 2000:152-7). Hamka's pre-war engagement with defending his works as works of literature found its continuation in the 1950s, when he again engaged in a polemic with writers and critics from Java on the quality of literature from Sumatra. In 1999, a former Medan author of popular fiction, Zainuddin Pangaduan Lubis, made a convincing plea for a reappraisal of fiction from Medan. He pointed to the pioneering role of Islamic publishers and Hamka's involvement in the development of the roman picisan, and stressed the contribution of these texts to the development of a national language (Zainuddin Pangaduan Lubis 1999). Also, after reading Maier's explorative essay (2004) on Hamka's ideas on art and literature and his works one cannot but think of Hamka's 'tales', as Maier calls them, as literature.

Before the war, Dutch language magazines in the Dutch East Indies had featured American comics, but they became really popular only after the war. In Medan for instance, Waktu featured a series of Dan Barry's comic Flash Gordon in 1954. American comic distributor King Feature Syndicate conquered the Indonesian market, and Alex Raymond's Rip Kirby, Wilson McCoy's Phantom, and Tarzan became familiar to a large Indonesian audience. In the late 1950s and early 1960s, Indonesians began to 


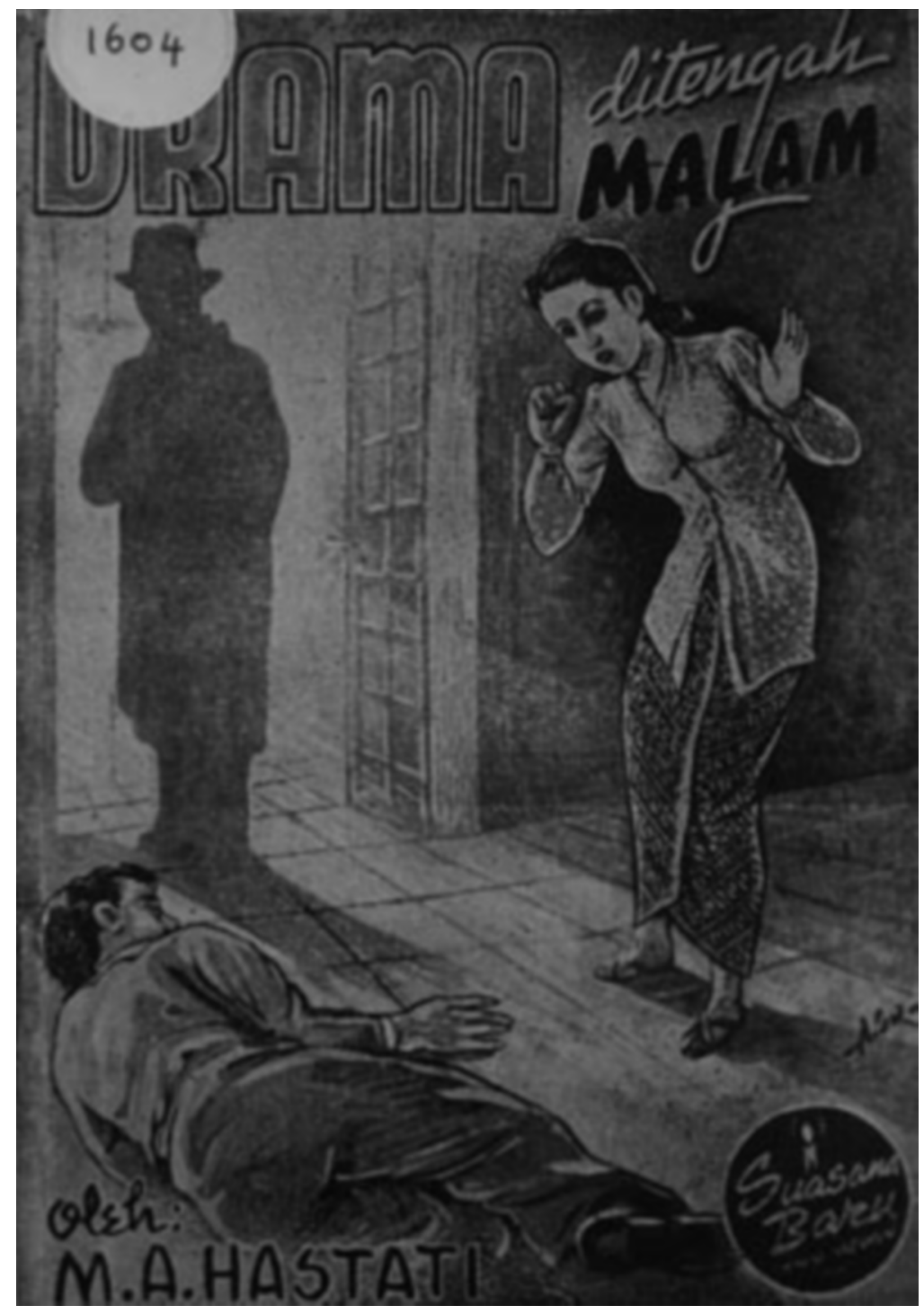

'Drama ditengah malam'. (M.A. Hastati) 
create comic works that reflected the social and political issues of the day. Comics - in Medan featuring characters from Batak folk lore, and in Java the wayang shadow play repertoire - emerged in response to the foreign domination of the world of comics. ${ }^{4}$ With the support of Mohammad Said, journalist and founder and main editor of Medan's prominent newspaper Waspada, Taguan Hardjo, a Dutch-Javanese immigrant from Suriname who had settled in Medan, became one of Indonesia's most popular comic artists. ${ }^{5}$

In light of the role of Jakarta as the nation's cultural centre, its contribution to Medan's popular culture was rather limited. Popular bands from all over Indonesia, including Medan, toured the nation and often settled in Jakarta for a short period to record their music and get public exposure in the national newspapers and magazines. ${ }^{6}$ And while the young writers, playwrights, painters and actors in Medan who partook in the 'serious' national culture regarded Jakarta as their point of orientation, the masses looked across the Malacca Straits, to Singapore, for the release of a new film featuring popular Malay movie stars such as P. Ramlee or Kasma Booty.

Since the 1920s, Penang and Singapore had been centres of popular culture of what is commonly known as the Malay World, of which Medan formed part. This geographical area comprised Southern Thailand, Malaya, Singapore, Sumatra and the coastal regions of Kalimantan, and was inhabited by peoples who shared the Malay language, Malay traditions and the Islamic faith. ${ }^{7}$ Kahn (2006) has shown that they were - and still are - in fact a more heterogeneous group of peoples than commonly thought. Their later classification by Malaya's political elite as 'ethnically Malay' since

4 Examples of early comics published in Medan are an Indonesian comic version of Jules Verne's A journey to the center of the earth, by M. Ali's [whose name is also spelt M. Ali, M. Ali's and M. Ali'e], a Bugis story Daeng Topo pendekar Bugis, by Sigajo, and Indra manusia adjaib, also by Sigajo. Publishers of comics were, amongst others, Semesta, Harris and Toko Buku Casso.

5 Ade Tanesia 2002:60-5. Taguan Hardjo was born in 1935 in Suriname, at that time still a Dutch colony. As the eldest of fourteen siblings he was drawn to art from a very early age. When his mother - of Dutch descent - returned to the Netherlands, Taguan joined his father - a Javanese - to West Sumatra. Shortly after, he left his family and went to Medan, where his career as a comic artist took off. Amongst Taguan Hardjo's most popular works are Abu Nawwas (1958 and 1960), Batas firdaus (1960), and Mentjari musang berdjanggut (1968), http://www.pragatcomic. com/forum/index.php?topic=607.0;wap2, (accessed 23-7-2009).

6 Peter Keppy, personal conversation, May 2009.

7 For recent discussions on the Malay world and Malay identity (politics), see Timothy P. Barnard (2004). In his compelling alternative literary history of Malay writing, Henk Maier (2004), using Malay texts, argues that the essence of 'Malayness' is heterogeneity, adaptability and a constant negotiating on what exactly constitutes 'Malayness'. 
the late forties served political ends and as such it became part of the official Malay national narrative, up to the present day. ${ }^{8}$

With the founding of two competing film studios in Singapore in 1947 and 1952 and the production of a large number of successful Malay films, Singapore became the centre of Malay film. The films were produced with Chinese capital, by Indian directors and with Malay actors. Film became a huge industry and drew to Singapore many Malays who wanted to try their luck as actors, playwrights or composers. The format of the early films was partly based on that of a form of popular Malay theatre called bangsawan, with an important role for music (Harper 1999:282-5).

Relatively many of those 'Malays' who travelled to Singapore to work in the film or related music industry came from Medan. It is striking that several key figures in the Singapore film business were exponents of the pre-war world of theatre (both bangsawan and modern theatre, called sandiwara), music and silent film in North Sumatra. The parents of the laureate composer Ahmad Jafa'ar for instance, were silent-cinema operators. He learned to play different musical instruments and performed in the orchestra that accompanied silent-movie showings. Singer Rubiah joined a travelling theatre group as a young girl, when her family could no longer afford to feed her. Achmad CB started his career before the war as a bangsawan actor; later he founded his own modern theatre group Asmara Dhana/Rayuan Asmara. Lastly, the popular movie star Kasma Booty was only fourteen when she joined Achmad CB's theatre group in Penang in order to escape persecution by the Japanese. All four had been travelling around the region and performing since they were young, and their move to Singapore and switch to the movies was just the next logical step in their career.

It is interesting to note that the three "champions of the Malay movie and song' from Medan, Rubiah, Achmad CB, and Kasma Booty were ethnically not Malay at all. They belonged to what Kahn has called the 'other Malays': Malayans or Indonesians of mixed ethnic origin, born and/or raised in the Malay regions. Rubiah's father was a Batak, her mother Javanese. Achmad CB had an Arab background (Said Tripoli, a renowned bangsawan actor and director, was his uncle), while Kasma Booty's father was Dutch.

In Singapore, 'The world of the movies, cabaret bands and starlets was a network of gifted individuals who set the tone of anti-colo-

8 Recently this stifling ethnic label has been challenged by Malaysian political activists and others who plea for the acknowledgment of the Malay heterogeneity. Political scientist Farish A. Noor is one of the leading advocates of this idea (see also the website The Other Malaysia, www. othermalaysia.org). 
nial politics' (Harper 1999:290). The Indonesian artists who arrived in Singapore met with nationalist writers, actors and musicians who had fled Malaya to escape the British Emergency Regulations. Together they were responsible for the radicalization of popular culture in Singapore (Harper 1999:290-1; Kahn 2006: 114-7).

\section{ACHMAD CB}

As an illustration of this fluid traffic of popular 'Malay' artists from Medan and their orientation to Singapore as cultural centre, I will elaborate on the life of singer-songwriter-theatre director Achmad CB. Born in 1915 in Medan into a Malay-Arab family as Achmad Awab Aziz, he was taken at the age of five by his father, a trader, to Malaya where he spent a large part of his youth. As a young man, he settled in Medan and became an active member of Gerakan Rakjat Indonesia (GERINDO, Indonesian People's Movement), a radical Marxist people's party. To spread the party's political ideas, he established the theatre group Asmara Dhana; the group mainly staged anti-colonial plays by the nationalist Muhamad Saleh Umar. It was because of his fierce anti-colonial attitude that Achmad Awab Aziz got the name he kept as his artist name: Achmad C(as) B(ara), meaning something like 'having a short fuse'.

As he was being closely watched by the Dutch intelligence service because of his political activities, he fled to Singapore. There, he recorded his songs at His Master's Voice and became a popular singer of Malay songs. With the onset of the Second World War, he moved back to Medan, and continued his work as leader of Asmara Dhana. After the war, during the Revolution, Asmara Dhana performed in North Sumatra to collect money for the freedom fighters of Nasional Pelopor Indonesia (NAPINDO, Indonesian National Pioneers). When the Dutch were after him, he fled to Malaya where he continued his benefit performances for the Indonesian nationalist cause.

Following international recognition of Indonesia's independence in 1949, Achmad stayed in Malaya and travelled back and forth to Singapore. With his group, renamed Rayuan Asmara, he dedicated himself to the struggle for an independent Malaya. He wrote many nationalist Malay songs that were sung at rallies and aired on the radio. His song 31 Ogos 1957 - named after the date of Malayan Independence - later became part of the Malaysian national history of the struggle for Independence. As an actor he featured in Malay movies. 


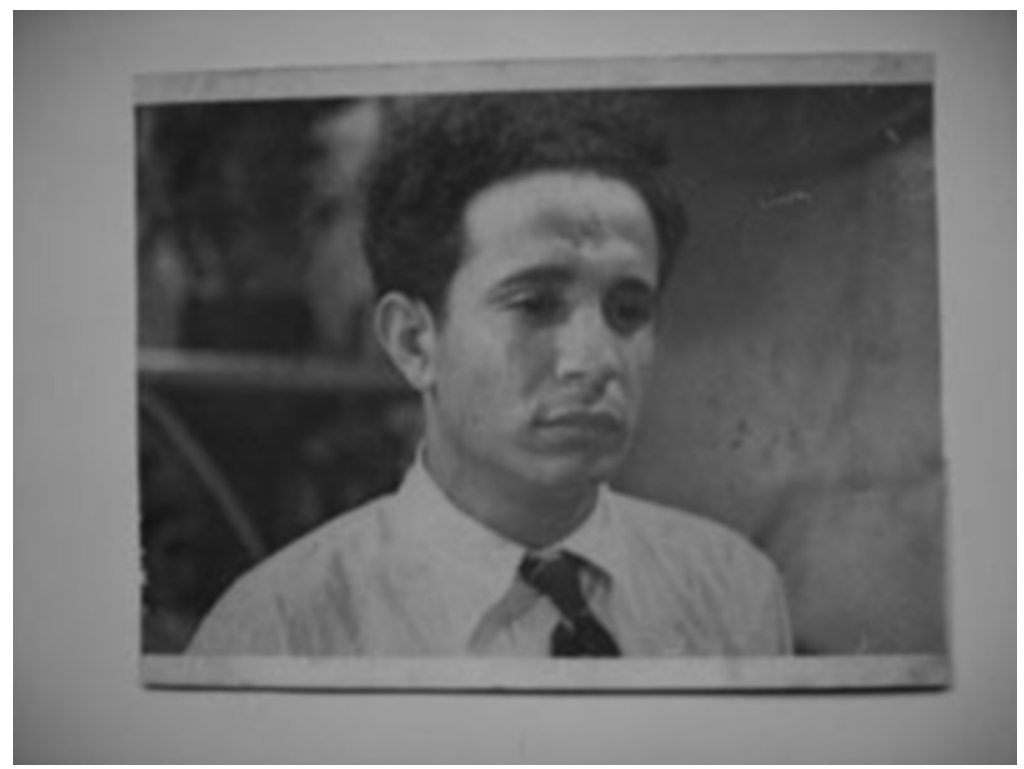

Achmad CB as a movie star in the 1950s. (collection Achmad CB)

Achmad established close connections with aspiring political leaders such as Tunku Abdul Rahman, who headed the United Malays National Organisation, and supported the UMNO in election campaigns. After Malayan Independence in 1957, the group followed Prime Minister Tunku Abdul Rahman on propaganda tours to Brunei and Sarawak. In 1963, after Konfrontasi had strained relationships between Indonesia and Malaysia, the Indonesian government banned Achmad's performances in Indonesia. As a 'Malay nationalist', the Indonesian government could not exactly place him; because of his former cultural-political activism in Malay[si]a, the Indonesians no longer trusted him. ${ }^{9}$

9 After 1965, Achmad CB became a supporter of Soeharto's New Order politics and composed several New Order propaganda songs. He kept performing with Asmara Dhana until around 1980. His active career spanned 45 years and four different regimes. From an innovative artist who rose to fame in the urban popular culture between 1935 and 1960, he became a marginalized artist in the 1970s, a remnant of the pre-war bangsawan tradition. However, his contribution to the Malaysian nationalist struggle was recognized by the Malaysian government. Until his old age, he was regularly invited to Kuala Lumpur to sing his song 31 Ogos 1957 on national television on Malaysian Independence Day. 
While forms of popular culture were enjoyed widely throughout most sections of Medan's population in the late 1950s, there was a much smaller audience for the more serious arts of modern Indonesian painting and literature. ${ }^{10}$ When, for instance, in July 1957 studieclub Sipongang in Medan organized a discussion program on literature for local writers and their public, the organizers were surprised that almost 50 people had shown up. ${ }^{11}$ At another literary event, the room was filled, but only with high officials from municipal and regional government institutions, who had felt unable to turn down an official invitation (Ramadhan K.H. 1952). Cultural and literary magazines were not commercially viable and the central government did not provide funds for literary publications (Barus Siregar 1953:25; Aan 1957). A few local newspapers and magazines featured cultural pages, but space was limited. ${ }^{12}$

Writing modern Indonesian literature in the 1950s was not just an act of self expression, or a means to earn money. The national cultural policy of the young republic centred on the formation of national culture that was modern and at the same time thoroughly Asian, and modern Indonesian literature was to form an important element of that culture. With this assignment in mind, Indonesia's writers and cultural critics realized what was at stake: the outlook of a national literature that was to form part of an Indonesian identity and at the same time would shape that identity. Yet the young age of the majority of writers in Medan - most of them were still in high school when their first work was published - meant that often other, less pretentious, motives prevailed, such as the wish to attract the attention of women ${ }^{13}$ or to become famous.

The young writers and wannabe-writers of modern Indonesian literature in Medan had to compete with writers from elsewhere in Indonesia to have their work accepted for publication in the

10 Modern theatre, on the other hand, enjoyed a wide popularity. There was a large number of amateur and semi-professional theatre groups in Medan, and performances drew large crowds. When LEKRA once staged one of Utuy Tatang Sontani's plays at an open-air stage on the beach at Pantai Cermin, the location could no longer be reached because of a traffic jam (Chalik Hamid, personal conversation, 21-9-2008). For more on theatre in North Sumatra, see Muhammad TWH 1992, and Michael Bodden 2010.

11 'Pertemuan sastera di Medan', Arena 3-14/15 (1 August 1957):28.

12 Cultural pages in local newspapers and magazines include 'Sipongang - Perumahan budaja - Sastera - bersama2 studi-klub "Sipongang", in Waktu, with editors Bokor Hutasuhut, Asri Mochtar and Sedar, and 'Seni dan Budaja' in Tugas, with editors M. Sutardjo Shahputra and Bahauddin Darus.

13 Astaman Hasibuan was one of the writers who specifically mentioned this motivation (Astaman Hasibuan, personal conversation, 14-1-2009). 
few national literary and cultural magazines published in Jakarta. ${ }^{14}$ Most poems and short stories by Medan authors that appeared in the magazines still reflected their native - regional - soil, as they centred upon themes such as North Sumatran kampung life, Christianity, local freedom fighters and the clash between an urban, modern life style and the constraints of family and tradition.

The authoritative status of one of the literary editors in Jakarta, Hans Bague Jassin (known as H.B. Jassin), becomes clear from the following citation from Hamsad Rangkuti's account (2003:xiii) of the start of his career as a writer in Medan:

At that time, the writers in Medan were competing with each other to have their stories published in the literary magazine Sastra in the nation's capital. Without telling anyone, I decided to send one of my short stories to Warta Dunia, another magazine published in Jakarta. The story did get published and I gained more self-confidence. Then, the most renowned author in Medan, Sori Siregar, contacted me and gave his reaction: he thought it was a really good story. He urged me to send it to Sastra as well, which I did. A month later I received a letter from Sastra stating that the story was accepted for publication. I felt as if I had won the lottery. [ ...] I possessed the one thing that would make the established writers in Medan acknowledge my status as a writer: the recognition of the literary quality of my work by HB Jassin. [ ... ] It was as if that letter from Sastra was the official decree that I was a writer.

Not everyone in Medan accepted the authority of the self-proclaimed cultural leaders in Jakarta. There were voices, such as the writer Hamka, which questioned the status of Jakarta as the nation's cultural centre. Hamka, of West Sumatran origin, had lived in Medan for ten years before he moved to Jakarta to work as an editor of Mimbar Agama. As he still felt closely connected to Sumatra, and Medan in particular, he promoted Sumatra's regional cultures in his writings and defended them against attacks by leading cultural figures from Java such as Aoh Karta Hadimadja and Trisno Sumardjo (Aoh Karta Hadimadja 1952; Dada Meuraxa 1957:143-7). Hamka argued that Jakarta could not pos-

14 Authors from Medan whose work was published in national magazines and newspapers included: Bokor Hutasuhut, Asri Mochtar, Sedar, Sori Siregar, Chalik Hamid, Herman KS (with the pen name Jalaludin), Abdul Aziz's, Agam Wispi, Ibrahim Sinik, Bakri Siregar, Djohan Arifin Nasution, H.A. Dharsono (with the pen name Harun Arrasyhid), Zainuddin Tamir Koto (with the pen name Zatako), Zakaria M. Passe, Hr. Bandaharo, and Aziz Akbar. The publication Khasanah; Biografi sastrawan Sumatera Utara by Ahmad Sani Siregar and Sabaruddin Ahmad is a useful source for biographical information on authors from North Sumatra (Dewan Kesenian Medan, 1986). See also Leksikon susastra Indonesia, by Korrie Layun Rampan (2000). 
sibly be the nation's cultural centre, as cities had never held that position in the past. The Indonesian cultural centres, he claimed, were to be found in the regional heartlands. He also criticized the cultural icons in Jakarta for their arrogance. When, for instance, Sutan Takdir Alisjahbana in Jakarta revised spelling and grammar rules without consulting Malay language specialists from outside Java, Hamka expressed his strong disapproval. He felt that the Malays, as native speakers of the Malay language, were the true custodians of the national language, Bahasa Indonesia, and should be allotted a role in the development of that language (Dada Meuraxa 1957:151-2). Others felt that the cultural icons in Jakarta had no right to dictate the outlook of modern Indonesian literature and argued that Medan writers themselves should be involved in the evaluation of literary works.

For Malay writers and journalists, their mother tongue combined with basic writing skills was their entry ticket to world of literature and journalism. Thus it is not surprising that a relatively large group of writers of modern Indonesian literature originated from North Sumatra. There were many writers from Medan who moved to the nation's capital and cultural centre to be close to where it all happened. A quick search through the list of editors of these magazines reveals several influential writers of North Sumatran origin. ${ }^{15}$

One aspect of the cultural world of Medan in the fifties that strikes the eye is the role of certain individuals from Java in the development of modern literature and theatre. Cultural Manifesto (Manifes Kebudayaan)-signatory Bokor Hutasuhut, one of the main initiators of cultural activities in Medan during the fifties, declares how he and his writer-friend Alie Soekardi as high school students were introduced to modern Indonesian literature by the cultural page of local newspaper Mimbar Umum edited by Aoh Karta Hadimadja. Aoh was an influential writer and literary critic from Java, who worked in Medan as a journalist with Mimbar Umum in 1950-1952. His columns on modern Indonesian culture led to debates with local artists on the status of regional culture.

At that time, Bokor was a student at the Pembaruan High School, which was led by another individual who would become a cultural icon (of LEKRA signature), Bakri Siregar. After having studied Old Javanese literature in Java, Siregar had become a language teacher at a high school in Kota Radja (now Bandar Aceh) in Aceh. In 1950 he moved to Medan, taking several of his students with him. ${ }^{16}$

15 Sobron Aidit, Bakri Siregar and Hr. Bandaharo, for example.

16 Amongst them were F.L. Risakotta, a young writer who later moved to Jakarta to become an influential member of LEKRA, and the later essayist and head of LEKRA in North Sumatra, Aziz Akbar. 
As head of the Pembaruan school, and teaching at other Medan schools as well, he was able to guide a large group of students into the world of modern literature and theatre. ${ }^{17} \mathrm{~A}$ short time after Siregar's arrival in Medan,${ }^{18}$ he managed to become a leading figure in the city's cultural field as head of LEKRA ${ }^{19}$ (Dharsono 1959; Korrie Layun Rampan 2000:83).

Lastly, with the arrival in Medan of communist Chinese refugees from Java in 1959 - after the central government had issued anti-Chinese regulations in the Peraturan Pemerintah 10 - relations between LEKRA and LKN affiliated cultural workers and their non-leftist colleagues deteriorated. Tan Fhu Kiong for instance, founded and edited the newspaper Harian Harapan, trumpet of the communists, and regularly launched personal attacks on writers who had not committed themselves to the communist cause.

Another important factor in the city's cultural arena was the national army. Army leaders were held in high esteem by the city's inhabitants and were present at inaugurations and performed as keynote speakers at public and cultural events. From the early fifties onwards, local army leaders acted as important patrons of the arts. They financed performances of modern theatre, participated in the organization of cultural events, and some were active themselves as musicians, playwrights or writers. Letnan kolonel M. Nur Nasution, for instance, supported initiatives by Bokor Hutasuhut in the field of theatre. He paid the rent of the venues, wrote plays and guided the young actors. When LEKRA became active in Medan, the army increased its financial support to LEKRA's adversaries in an attempt to counteract LEKRA's political propaganda. ${ }^{20}$

MALAY NATIONAL LITERATURE IN THE FIFTIES: THE SINGAPOREJAKARTA CONNECTION

In the same period, on the other side of the Malacca Straits, Singapore was developing into a hub of Malay political activism. The city

17 Bokor Hutasuhut has told how Siregar allegedly showed his disappointment at Bokor's refusal to follow in his teacher's (leftist) footsteps by not letting him pass his Indonesian language exams, on exactly the same day that Bokor won a national literature contest (Bokor Hutasuhut, personal conversation, October 2009).

18 After his move to Jakarta, he became member of the central board of LEKRA and head of Lembaga Seni Drama (LESDRA, the Institute of Dramatic Art under LEKRA).

19 Chalik Hamid, personal conversation and communication by e-mail, September 2008 and 2009; Bokor Hutasuhut, personal conversation, October 2009; Alie Soekardi, personal conversation, October 2009.

20 Bokor Hutasuhut, personal conversation, October 2009. 
was outside the restrictive control by the Malay courts, so that new ideas that challenged the established order could be developed and disseminated. Moreover, technological innovations - especially in the publishing and film industries - found fertile ground and aided Malay nationalist cultural workers in their efforts to establish a Malayan nation (Barnard and Van der Putten 2009). There were several Malay nationalist writers from Singapore who maintained close personal relationships with key literary figures from modern Indonesian literature. These relations were formed in the framework of nationalism. The fundaments for this transnational literary network date back from before the war. Already in the 1920s, the young, nationalist, Malay reformist Muslims from rural areas, the so-called kaum muda, were inspired by anti-colonial literary writings from Indonesia. When these young nationalists in 1937 gathered in the Kesatuan Melayu Muda (KMM, Union of Malay Youth) - the first peninsula-wide Malay political organization - the KMM's paramount goal was the formation of an independent nation consisting of a united Malaya and Indonesia: Melayu Raya or Indonesia Raya.

Near the end of the war, the KMM gained momentum when the Japanese urged KMM leaders to make preparations for the Malayan Independence that seemed immanent. But when Soekarno and Hatta, pressured by young revolutionary nationalists, hastily proclaimed Indonesian Independence on 17 August 1945, they left their Malay 'brothers in arms' - with their plans for a Melayu Raya - empty-handed.

After the war, the struggle for Melayu Raya was continued by the Malay National Party (MNP) founded by KMM leaders Burhanuddin al-Helmy, Ishak Haji Muhammad and Ahmad Boestamam. But the party soon lost terrain to the conservative nationalist Malays of the United Malays National Organisation (UMNO). Moreover, when the British declared the Malayan Emergency in 1948 in reaction to a communist armed revolt on 18 June, strict regulations regarding anti-British political activity paralyzed the MNP and made political activists flee to Singapore. When the party was formally banned in 1950, the struggle for Indonesia Raya came to an end (Soh 2005).

Such was the political background of most of the Malay nationalist writers that settled in Singapore around 1950. Budiawan, in his contribution to this volume gives an analysis of the contacts between these writers in Singapore and their Indonesian counterparts in Jakarta. Many of the Malays authors in Singapore were former MNP members and were highly influenced by Indonesian literature and Indonesian nationalist thought. Even the name of the Malay writers' association in Singapore, Angkatan Sastrawan 1950 (ASAS 50), was modelled after the name Angkatan 1945 (the 
1945 Generation), which designated the new generation of Indonesian writers that emerged after the Second World War. Several ASAS 50 members had close personal relationships with contemporary Indonesian writers (see Budiawan, this volume).

As Barnard and Van der Putten (2009) have shown, for the Malay nationalists the Malay language and literature and its modernization were pivotal in the formation of a unified Malaya. The nationalists regarded Malay as the most suitable alternative to English, the latter being too tainted by the British colonial enterprise. It is interesting to note that these Malay writers of modern literature on the Malayan Peninsula turned to the established writers of modern Indonesian literature in Jakarta for inspiration, instead of to their fellow Malay writers on the east coast of Sumatra (who were, in their turn, oriented towards Jakarta as well). As far as I have been able to research, there is no data available that suggests the existence of personal links between writers of modern Indonesian literature in Medan, such as Bokor Hutasuhut, Hr. Bandaharo, Bakri Siregar, Sori Siregar and Herman KS, with the Malay writers of modern literature in Singapore. This is the more striking when one takes into account the fact that many of the Singapore writers were of leftist inclination. Before and during the war, there had been close ties between the communists on either side of the Straits; this makes the absence of links between the leftist writers of modern literature in Medan and Singapore even more remarkable. Moreover, the literary manifesto of ASAS 50 resembled that of LEKRA in its concern for the lives of the common people, but while LEKRA was a strong contender in Medan's cultural arena in the late 1950s, to date I have found no data to suggest contacts between Singapore ASAS 50 writers and leftist writers in Medan.

In his essay in this volume, Budiawan gives several reasons for this. First, in the early 1950s, LEKRA was still trying to gain ground in the Indonesian cultural field. This is supported by the statement of Astaman Hasibuan, former head of the Medan branch of LEKRA, that it was initially extremely difficult to convince artists in Medan and other North Sumatran cities to join LEKRA. Writers, in particular, were unwilling to sign up, as they did not need an organization's support to be able to write. Dancers, musicians and actors, on the other hand, were the first to commit themselves to LEKRA's cause, as their performances - in ensembles and theatre groups - benefited from LEKRA's organizational means. ${ }^{21}$ Second, the national movement in Malaya was ultimately taken over by more conservative forces, marginalizing the left wing nationalists. Lastly, with UMNO's dominance in the national movement, the promo- 
tion of 'Malayness' in relation to 'nationhood' was more important than the issue of social justice promoted by the leftist nationalists.

\section{CLOSING REMARKS}

After Indonesian independence, cultural workers in Jakarta and other cities on Java claimed a dominant role in the discussion about the construction of an Indonesian national culture. National media channelled their voices to reach all corners of the nation, including Medan. Artists and cultural critics from outside Java reacted at once and began to participate in the debate on and the construction of a homogeneous culture that would 'fit' all Indonesians as a comfortable garment. This formed the onset of a continuous exchange of ideas, literary products, critique, and cultural workers between Medan and Jakarta.

On the one hand, the nation's capital functioned as a magnet; it attracted young journalist/writers from Medan, well versed in the Malay language, and seeking career opportunities. A relatively large number of the writers and editors of the nation's newspapers and magazines originated from Medan and other parts from North Sumatra, and were able to influence the debate on national culture. It was particularly the leftist writers from Medan who later moved to Jakarta, such as Hr. Bandaharo, Agam Wispi and Bakri Siregar, who became important players in the national cultural field, especially from the early 1960s on when the Left got Soekarno's backing. From Jakarta and other cities in Java, writers, poets, and actors travelled to Medan to perform or give presentations on their work. In the $1950 \mathrm{~s}$, there was not yet the deep divide between the leftist and the other cultural organizations in Medan that characterized the early sixties. Friendly relations between artists of different political conviction, and cooperation between them in cultural activities prevailed. In such an atmosphere, it was not strange to find LEKRA icon Pramoedya Ananta Toer from Java giving a lecture at a Medan teacher training college where the majority of teachers were anti-communist.

At the same time however, Medan-based artists criticized, what they called, the 'arrogant' attitude of their colleagues in Jakarta. After having worked in Medan for more than a year, Aoh Karta Hadimadja concluded that Sumatran culture had nothing worthwhile to contribute to a national culture. Others in Java shared his opinion. This mentality, as is not hard to imagine, highly annoyed the Sumatrans.

But culture includes more than 'high' arts alone, and for a large number of Medan's inhabitants, Singapore was the cultural centre, 
not Jakarta. The city formed part of a Malay transborder exchange network of urban areas with a large amount of cultural traffic between them. Its lines of exchange dated back to the first decades of the twentieth century, when bangsawan theatre groups from either side of the Straits toured the Malay world (Cohen 2002). The transborder cultural contacts in the 1950s were based on a sort of cosmopolitan-ethnic 'all-inclusive Malay' identity, and had nothing to do with Indonesian nation building, as was the case with the more serious Indonesian arts. Singers, actors and composers from Medan went to Singapore to work in the film industry, while the finished products records and Malay movies - were imported by cinema directors and music stores in Medan. Besides film related cultural traffic, pulp fiction from Medan was printed in jawi script especially for the Malayan market.

The nationalist Malay writers in Singapore sought allegiance with their 'elder brothers' of the modern Indonesian nation, instead of with their fellow 'Malays' in Medan. It was the attraction of a modern nation-state and the role a national literature could play in the formation of a nation that made the Malays in Singapore turn to modern Indonesian literature. Indonesians and Malays were, after all - like the Malays living on both sides of the Malacca Straits, bambu serumpun, of the same stock.

After 1958, the cultural scene in Medan became increasingly politicized. Cooperation between members of LEKRA and LKN and the other cultural organizations gradually came to a halt. Newspapers backing the PKI openly pilloried the so-called bourjuis writers and actors, and banners with the names of targeted writers appeared in the streets. In 1964, many Medan writers/journalists lost their jobs, because they did not back the policy of the Indonesian Journalists' Union, (Persatuan Wartawan Indonesia, PWI) which by then was already taken over by the Left.

For a complete view of the cultural life in Medan in the 1950s, further research is needed. Besides the map drawn in this article, there existed other maps and/or exchange networks. Available sources suggest the existence of Chinese, Batak, 'traditional' Malay, and Islamic cultural circles. One might ask if and to what extent they formed part of exchange networks and whether or not they were mutually exclusive. Besides, until 1958, the Dutch influence on culture in Medan was considerable. Lastly, the backdrop of the Cold War puts Medan in a world perspective. An investigation into the cultural missions, visits and exchanges organized by the two power blocs in an attempt to spread their ideologies, and by Medan cultural workers themselves will throw more light on the nature of this international exchange network and its influence on local artists. 
REFERENCES

Aan

1957

'Kegiatan kesusastraan di Medan', Mimbar Indonesia 11-6:19, 23.

Ade Tanesia

2002

'Wid N.S.; Comic crusader', Latitudes 21:60-5.

Ahmad Sani Siregar and Sabaruddin Ahmad

1986 Khasanah; Biografi sastrawan Sumatera Utara. Medan: Dewan Kesenian Medan.

Aoh K. Hadimadja

1952 'Kehidupan kesusastraan di Sumatra', Kompas 2-11 (July):30-2.

Barnard, Timothy P. (ed.)

2004 Contesting Malayness; Malay identity across boundaries. Singapore: Singapore University Press.

Barnard, Timothy P. and Jan van der Putten

2009

'Malay political activism in post-war Singapore' in: Michael

D. Barr, Carl A. Trocki (eds), Paths not taken; Political pluralism in post-war Singapore, pp.132-53. Singapore: NUS Press.

Barus Siregar

1953 'Penerbit-penerbit Medan', Kompas 3-2 (15 February):20-6. Bodden, Michael

2010 'Modern drama, politics, and the postcolonial aesthetics of left-nationalism in North Sumatra; The forgotten theater of Indonesia's Lekra, 1955-65', in: Tony Day and Maya H.T. Liem (eds), Cultures at war; The Cold War and cultural expression in Southeast Asia, pp. 46-80. Ithaca, NY: Southeast Asia Program (SEAP), Cornell University. [Studies on Southeast Asia 51.]

Buku tahunan

1955 Buku tahunan kota besar Medan tahun 1954. Medan: Djawatan Penerangan Kota Besar Medan.

Cohen, Matthew Isaac

2002 'Border crossings; Bangsawan in the Netherlands Indies in the nineteenth and early twentieth centuries', Indonesia and the Malay World 30-87:101-15.

Conboy, Kenneth J.

2003 Kopassus; Inside Indonesia's special forces. Jakarta: Equinox.

Dada Meuraxa 
[1957?] Inspirasi pudjangga. Medan: Kaproco.

Dharsono, H.A.

1959

'Pidato Bakri Siregar jang amis di Solo', Konfrontasi 30:3-8.

Feith, Herbert

$1999 \quad$ Pemilihan umum 1955 di Indonesia. Jakarta: Kepustakaan Populer Gramedia. [Originally published as The Indonesian elections of 1955. Ithaca: Modern Indonesian Project, Southeast Asia Program, Cornell University, 1957 (Interim report series).]

Foulcher, Keith 1986

Social commitment in literature and the arts; The Indonesian 'Institute of People's Culture' 1950-1965. Clayton: Southeast Asian Studies, Monash University. [Monash papers on Southeast Asia 15.]

Frederick, William H.

1982 'Rhoma Irama and the dangdut style; Aspects of contemporary Indonesian popular culture', Indonesia 34:103-30.

Hamsad Rangkuti

2003

Bibir dalam pispot. Jakarta: Buku Kompas.

Harper, T.N.

1999

The end of empire and the making of Malaya. Cambridge: Cambridge University Press.

Kahn, Joel S.

2006

Other Malays; Nationalism and cosmopolitanism in the modern Malay world. Singapore: Singapore University Press, Copenhagen: NIAS Press. [Southeast Asia publications series.]

Korrie Layun Rampan

2000 Leksikon susastra Indonesia. Jakarta: Balai Pustaka.

Kratz, E. Ulrich

1991 'Criticism and scholarship; The study and teaching of Indonesian literature in a non-Indonesian context', in: J.J. Ras and S.O. Robson (eds), Variation, transformation and meaning; Studies on Indonesian literatures in honour of $A$. Teeuw, pp. 191-209. Leiden: KITLV Press. [Verhandelingen 144.]

2000 'The canon of Indonesian literature; An analysis of available Indonesian histories of Indonesian literature', in: David Smyth (ed.), The canon in Southeast Asian literatures; Literatures of Burma, Cambodia, Indonesia, Laos, Malaysia, the Philippines, Thailand and Vietnam, pp. 147-71. Richmond, 


\section{Surrey: Curzon.}

Maier, Henk

2004

We are playing relatives; A survey of Malay writing. Leiden:

KITLV Press. [Verhandelingen 215.]

Muhammad TWH

1992

Sejarah teater dan film di Sumatera Utara. Medan: Yayasan Pelestarian Fakta Perjuangan Kemerdekaan R.I.

Nasution, M.

1955

'Apa jang dibatja Medan', Buku Kita 1-6:261.

Pelzer, Karl

1982

Planters against peasants; The agrarian struggle in East Sumatra 1947-1958. 's-Gravenhage: Nijhoff. [KITLV, Verhandelingen 97.$]$

Ramadhan K.H.

1952 'Ada malam seni di Medan', Zenith 2-6:92-7.

Rhoma Dwi Aria Yuliantri and Muhidin M. Dahlan (eds)

2008 Lekra tak membakar buku; Suara senyap lembar kebudayaan Harian Rakyat 1950-1965. Yogyakarta: Merakesumba.

Soh, Byungkuk

2005

'Ideals without heat; Indonesia Raya and the struggle for independence in Malaya, 1920-1948', Wacana 7-1:1-28.

Stoler, Ann Laura

1995

Capitalism and confrontation in Sumatra's plantation belt, 18701979. Second edition. Ann Arbor: Univ. of Michigan Press.

Teeuw, A.

1986 Modern Indonesian literature, vol. I. Third edition. Dordrecht: Foris Publications.

Zainuddin Pangaduan Lubis

1999

'Roman 'picisan' dan kita'. [Manuscript.] 